\title{
Subset of Natural Killer Cells Is Induced by Immune Complexes to Display Fc Receptors for IgE and IgA and Demonstrates Isotype Regulatory Function
}

\author{
Hajime Kimata and Andrew Saxon \\ Division of Clinical Immunology and Allergy, Department of Medicine, University of California at Los Angeles \\ School of Medicine, Los Angeles, California 90024
}

\begin{abstract}
Expression of Fc receptors for IgE (FcER) or IgA (FcAR) on purified natural killer (NK) cells was investigated. No FcER+ and a few FcAR + NK cells were detectable on freshly separated NK (NKH-1 + ) cells from normal donors. Incubation of NK cells with IgE-anti-IgE immune complexes or IgA-antiIgA immune complexes induced up to 10 and $20 \%$ FcER+ or FcAR + cells, respectively. These FcR were induced on CD3but not on CD3 + NKH-1 + cells. In contrast, NK cells from patients with various dysgammaglobulinemias could not be induced to express FcER or FcAR corresponding to their abnormal circulating IgE and/or IgA levels. Enriched FcER+ or FcAR + induced NK cell supernatants from normals enhanced IgE or IgA synthesis from Ig secreting B cell lines in an isotype-specific fashion without increasing proliferation. Thus NK cells, after interaction with specific Ig isotypes in complexes, express FcR and produce differentiation factors for that isotype.
\end{abstract}

\section{Introduction}

An increasing body of data suggests that immunoglobulin Ig isotypes involved in antibody responses are regulated by cells expressing Fc receptors for specific isotypes (1-3). T cells expressing receptors for $\operatorname{IgE}(\mathrm{FcER})^{1}$ or $\operatorname{IgA}(\mathrm{FcAR})$ have been detected and induced on human peripheral blood lymphocytes (4-8). Additionally we reported that $T$ cells exposed to immune complexes (IC) formed by IgE and anti-IgE (IgE-IC) were activated, presumably through FcER, to specifically inhibit IgE synthesis (9). However, the T cell fractions employed in those studies were isolated by sheep red blood cell (E) roset-

Presented in part at the Collegium Internationale Allergologicum in Goteborg, Sweden, August 1986.

Address reprint requests to Dr. A. Saxon, Division of Clinical Immunology and Allergy, Department of Medicine, University of California, Los Angeles, School of Medicine, 10833 Le Conte Avenue, Los Angeles, CA 90024-1736.

Received for publication 22 July 1987 and in revised form 12 January 1988.

1. Abbreviations used in this paper: $\mathrm{BCDF}, \mathrm{B}$ cell differentiation factors; CVI, common variable immunodeficiency; E receptor, sheep erythrocyte receptor; FcAR, Fc receptors for IgA; FcER, Fc receptors for IgE; FcGR, Fc receptors for IgG; FcR, Fc receptors; IC, immune complexes; IgA-IC, IgA-anti-IgA immune complexes; IgE-IC, IgEanti-IgE immune complexes, IL-2R, interleukin 2 receptor; NK, natural killer cells.

J. Clin. Invest.

(C) The American Society for Clinical Investigation, Inc. 0021-9738/88/07/0160/08 \$2.00

Volume 82, July 1988, 160-167 ting methods and thus contained natural killer (NK) cells which bear low affinity E receptors (10). Human NK cells are known to express Fc gamma receptors (FcGR) (11) while FcER or FcAR on human NK cells have not been well defined. It has been reported that some NK cells express the FcER both in mice and human $(12,13)$. It has also been reported that human NK cells were able to produce B cell differentiation factors (BCDF) (14).

We have previously shown that human NK cells are capable of inhibiting, via a cytolytic mechanism, ongoing IgE synthesis from the human IgE myeloma cell line (U266/AF-10) (15). This inhibition could be reversed by incubating the NK cells with IgE-IC. The apparent reversal of inhibition was, in fact, due to enhancement of IgE synthesis from the remaining non-lysed AF-10 cells, induced by IgE-IC stimulated NK cells, rather than decreased NK cytotoxicity. On the other hand, NK cells not only failed to lyse IgA secreting cell line GM-1056 or IgG secreting cell line GM-1500 but also enhanced IgA or IgG synthesis from those cell lines. This enhancement was not modulated by IgE-IC incubation of NK cells. These results indicated that incubation of NK cells with IgE-IC resulted in enhanced IgE synthesis in an isotype-specific fashion. In the present investigation, we studied the induction of FcER or FcAR on purified human NK cells (NKH-1+) and subsets (NKH-1 +/CD3- or NKH-1+/CD3+) from normal donors by IgE-IC or IgA immune complexes (IgA-IC). Patients with disturbances of circulating Ig levels were also investigated to examine the effects of in vivo exposure to abnormally high or low IgE or IgA levels. We also tested the functional ability of IgE-IC or IgA-IC stimulated NK cells from normal donors or patients to enhance IgE or IgA synthesis from B cell lines. Finally, we examined the prediction that FcER+ or FcAR+ NK cells, enriched by immune adherence, could secrete factor(s) that regulate ongoing Ig synthesis in an isotype-specific fashion.

\section{Methods}

Cell separation. Human mononuclear cells were isolated from heparinized venous blood of normal volunteers or patients with various disturbances of circulating Ig levels by buoyant density centrifugation on Ficoll-Hypaque. Usually $200 \mathrm{ml}$ of blood were obtained although when $\mathrm{NKH}-1^{+}$cells were separated into $\mathrm{CD}^{+}$or $\mathrm{CD}^{-}$populations, $300-400 \mathrm{ml}$ were taken. Sheep red blood cell binding cells ( $\mathrm{T}$ cells) were purified from the mononuclear cells by the 2-aminoethylisothiouronium bromide (AET; Sigma Chemical Co., St. Louis, MO)-treated E rosette technique $(16,17)$.

Patients. Blood samples were obtained from the following patients. Hyper-IgE immunodeficiency ( $n=3$, serum IgE 24,000, 44,000, and $46,200 \mathrm{ng} / \mathrm{ml}$; IgA levels normal), atopic dermatitis ( $n=3$, serum IgE $1,540,5,940$ and $24,200 \mathrm{ng} / \mathrm{ml}$; IgA levels normal), IgA myeloma ( $n$ $=2$, IgA 1,460 and $4,400 \mathrm{mg} / \mathrm{dl}$, IgE 72 and $120 \mathrm{ng} / \mathrm{ml}$ ), selective IgA 
deficiency ( $n=2$, IgA $<5 \mathrm{mg} / \mathrm{dl}$, IgE 8 and $24 \mathrm{ng} / \mathrm{ml}$ ), dysgammaglobulinemia type I $(n=1, \operatorname{IgA}<5 \mathrm{mg} / \mathrm{dl}, \operatorname{IgE}<80 \mathrm{pg} / \mathrm{ml}$, IgM 1,000 $\mathrm{mg} / \mathrm{dl}$ ), common variable immunodeficiency (CVI, $n=3$, IgA $<5$ $\mathrm{mg} / \mathrm{dl}$, IgE $<80 \mathrm{pg} / \mathrm{ml}$ ). Serum IgE was measured by our radioimmunoassay (lower limit $80 \mathrm{pg} / \mathrm{ml}$ ) (9).

Purification of NK cells. NK cells were purified from $\mathrm{T}$ cells by a modification of immune adherence as described $(15,18)$. Initially we tried to use anti-Leu 11 (CD16) antibody $(19,20)$, which detects Fc gamma receptor (FCGR) on NK cells; however, enriching by anti-Leu 11 antibody modulated the FcGR, thus we could not check the purity of NK cells by anti-Leu 11. Moreover this antibody altered cytotoxicity (20 and our personal observation). Therefore we used NKH-1 antibody (21), which did not have these unwanted effects. SRBC binding cells were adjusted to $6 \times 10^{7} / \mathrm{ml}$ in PBS with $5 \%$ fetal calf serum (FCS; Irvine Scientific, Santa Ana, CA) and incubated with mouse monoclonal antibody NKH-1 (mouse IgGl; Coulter Corporation, Hialeah, FL) at $0.25 \mu \mathrm{g} / 10^{6}$ cells for $60 \mathrm{~min}$ at $4^{\circ} \mathrm{C}$. The cells were then centrifuged and resuspended at $5 \times 10^{6} / \mathrm{ml}$ in PBS with $5 \% \mathrm{FCS}$ and poured into $100 \mathrm{~mm}$ plastic petri dishes (Dispo petri dishes; Miles Laboratories, Naperville, IL). Each dish had been incubated for overnight at $4^{\circ} \mathrm{C}$ with $6 \mathrm{ml}$ of $\mathrm{F}(\mathrm{ab})^{\prime} 2$ goat anti-mouse IgG Fc $(20 \mu \mathrm{g} / \mathrm{ml})$ (Jackson Immunoresearch Laboratories, Inc., Avondale, PA) followed by the addition of $15 \mathrm{ml}$ of PBS with 5\% bovine serum albumin (BSA, Sigma), incubated for $1 \mathrm{~h}$ at room temperature then washed three times with PBS and once with PBS with $1 \%$ FCS. After 90 min incubation at $4^{\circ} \mathrm{C}$, the nonadherent $\mathrm{T}$ cells (NKH-1-/CD3+ cells) were removed by gentle swirling and aspiration. After four more plate washes, the adherent (NKH-1+, here designated NK) were removed by vigorous washing. In both normal subjects and patients, the yield of NK cells was 5-15\% of $\mathrm{T}$ cell fraction and purity of NK cells were the same between normals and patients. NKH-1-/CD3+ cells contained $<1 \% \mathrm{NKH}-1+$ cells and more than $95 \% \mathrm{CD} 3+$ cells as determined by flow cytometry. The NK population contained $>95 \%$ of NKH-1 + cells by indirect immunofluorescence with NKH-1 antibody and fluorescein conjugated anti-mouse IgG (Zymed Laboratories, San Francisco, CA), more than 90\% CD 16+ (Leu 11+) cells, $<5 \%$ CD3+ (Leu 4+) cells, $<1 \%$ $\mathrm{CD} 20+(\mathrm{B} 1+)$ cells and $<0.5 \%$ monocytes as determined by nonspecific esterase staining. Since NKH-1 reacts with a minor $\mathrm{T}$ cell subset (19) in some experiments $\mathrm{NKH}-1+$ cells were further separated into NKH-1 +/CD3 - or NKH-1 +/CD3 + cells by panning using anti-Leu 4 (Becton Dickinson Monoclonal Center, Inc., Mountain View, CA). The yield of NKH-1+/CD3- and NKH-1+/CD3+ cells was 85-90\% and $3-4 \%$ of $\mathrm{NKH}-1+$ cells, respectively. NKH-1 +/CD3 - cells contained more than $95 \% \mathrm{NKH}-1+$, more than $95 \% \mathrm{CD} 16+$ cells, and less than $1 \%$ CD3 + cells, while NKH-1+/CD3 + cells contained more than 95\% NKH-1+, less than $1 \% \mathrm{CD} 16+$, and more than $95 \% \mathrm{CD} 3+$ cells.

Induction of FcER or FcAR on NK cells by immune complexes (IC). IgE-anti-IgE immune complexes (IgE-IC) were prepared by mixing purified human IgE (PS) with mouse IgGl monoclonal anti-IgE antibody (CIA 7.12) at an IgE to anti-IgE ratio of $2: 1$ at $37^{\circ} \mathrm{C}$ for $1 \mathrm{~h}(9,22)$. IgA-anti-IgA immune complexes (IgA-IC) were constructed by mixing purified human IgA (N.L. Cappel Laboratories, Westchester, PA) with mouse IgGl monoclonal anti-IgA antibody (CHE B6 clone, kindly provided by Dr. John Kearney, University of Alabama, Birmingham, $\mathrm{AL}$ ) at a ratio of $1: 2$. These complexes were found in preliminary experiments to provide for optimal induction of $\mathrm{Fc}$ receptors. NKH-1+, NKH-1+/CD3-, NKH-1+/CD3+ or NKH-1-/CD3+ cells $\left(2 \times 10^{6} / \mathrm{ml}\right)$ were cultured with medium alone, RPMI 1640 (M.A. Bioproducts, Walkersville, MD) supplemented with 10\% FCS (Irvine Scientific), $2 \mathrm{mM}$ glutamine, $50 \mathrm{U} / \mathrm{ml}$ penicillin, and $50 \mu \mathrm{g} / \mathrm{ml}$ streptomycin (CRPMI) or medium plus $0.1 \mu \mathrm{g} / \mathrm{ml}$ (unless otherwise indicated) of IgE-IC or IgA-IC in $13 \times 100 \mathrm{~mm}$ tissue culture tubes (Falcon Labware, Co., Oxnard, CA) at $37^{\circ} \mathrm{C}$ in a humidified incubator containing $5 \% \mathrm{CO}_{2}$ in air. After $16 \mathrm{~h}$ incubation (unless otherwise indicated), the cells were washed four times with copious amounts of $37^{\circ} \mathrm{C}$ medium and assessed for the presence of the FcER, FcAR, and FCGR and an aliquot of the cells added to Ig secreting cell lines. After incubation with medium or IC more than $95 \%$ of cells were viable, and the percent of NKH-1+, CD16+, CD3+, CD20+ cells or monocytes was not changed. To investigate the requirement for the induction of FcR by IC, NK cells were cultured with IC in the presence of cycloheximide $50 \mu \mathrm{g} / \mathrm{ml}$ or actinomycin D at $0.4 \mu \mathrm{g} / \mathrm{ml}$ (both from Sigma). In other experiments, irradiated (1,000 rad) NK cells were incubated with IC. NK cells were also incubated with IgE-IC formed between heat $\left(56^{\circ} \mathrm{C} \times 3 \mathrm{~h}\right)$ inactivated PS IgE and monoclonal anti-IgE. Heattreated IgE is unable to bind FcER (23) but is still able to be bound by monoclonal antibody CIA 7.12 as assessed by RIA.

Detection of FcER+ or FcAR+ cells. FcER + cells were detected by an immunohistochemical stain utilized binding of two different IgE-IC as previously described (22) and confirmed by using anti-FcER (CD23) monoclonal antibody. Cells were washed with PBS-azide and added to microcentrifuge tubes. To one set of tubes, $20 \mu \mathrm{l}$ of a $100-\mu \mathrm{g} / \mathrm{ml}$ solution of PS IgE/anti-IgE (7.12) IC, at a ratio of 2:1, was added. Negative controls received $20 \mu \mathrm{l}$ of $100 \mu \mathrm{g} / \mathrm{ml}$ of IgE-IC but of complexes constructed with heat inactivated $\left(56^{\circ} \mathrm{C}\right) \mathrm{PS}$ IgE. After $30 \mathrm{~min}$ on ice, the cells were washed, resuspended and centrifuged (Shandon Cytospin II) on to glass slides. The slides were incubated with $50 \mu \mathrm{g} / \mathrm{ml}$ of biotinylated horse anti-mouse IgG (Vector Laboratories, Burlingame, CA), washed with PBS and incubated with avidin-biotin horseradish peroxidase complex (also from Vector). After another wash, the slides were stained with freshly prepared 3-amino-9-ethylcarbazole at $0.4 \mathrm{mg} / \mathrm{ml}$ (Sigma) in $0.1 \mathrm{M}$ sodium acetate buffer ( $\mathrm{pH} 5.2$ ) plus $0.5 \%$ dimethyl formamide and $0.015 \% \mathrm{H}_{2} \mathrm{O}_{2}$. Slides were stained with Mayer's hematoxylin, mounted with immune-mount (Shandon) and examined under magnification 1,000 . At least 500 cells were counted. As a positive control for FcER, RPMI 8866 (24) was stained as above. Results are expressed as the percentage of specific FcER+ cells calculated as the percent of experimental cells stained (cells treated with IgE-IC) minus the percent of stained negative control cells (cells treated with heat inactivated IgE-IC). 70-95\% of RPMI 8866 (a known FcER+ cell line) were positive when stained by the IgE-IC while no RPMI 8866 were stained by heat inactivated IgE-IC. The sensitivity and specificity of this assay have been previously described (22). FcER + cells were also detected by using mouse IgGl monoclonal anti-FcER antibody (MAb-135), kindly provided by Dr. G. Delespesse, Montreal University, Montreal, Canada (25). Briefly, cells were incubated on ice for $\mathbf{3 0}$ min with $20 \mu \mathrm{l}$ of MAb-135 $(100 \mu \mathrm{g} / \mathrm{ml})$ instead of IgE-IC, then stained as above. FcER + cells were also detected using IgE-IC constructed with another human IgE myeloma protein (IgE kappa kindly provided by Dr. D. R. Stanworth) and anti-IgE (7.12) at a ratio of $2: 1.70-95 \%$ of RPMI 8866 were also measured as FcER positive as detected by MAb-135 or IgE-IC constructed with the IgE kappa myeloma protein.

FcAR + cells were detected in a similar fashion to FcER + cells, i.e., cells were incubated for $30 \mathrm{~min}$ on ice with $20 \mu \mathrm{l}$ of $\mathrm{IgA}-\mathrm{IC}(1 \mathrm{mg} / \mathrm{ml})$ at a ratio of 1:2 (IgA to anti-IgA) and then stained with anti-mouse Ig reagents as above. As a positive control for FcAR, the human promonocytic cell line (U937) was used. U937 was incubated with gamma-interferon (gamma-IFN) at $500 \mathrm{U} / \mathrm{ml}$ (Biogen, Cambridge, MA) for $16 \mathrm{~h}$ to induce FcAR. In preliminary experiments, we compared staining using $1 \mathrm{mg} / \mathrm{ml}$ of different ratios of IgA-IC (IgA to anti-IgA $2: 1,1: 1$, or 1:2), anti-IgA alone or IgA alone. After incubation with gamma-IFN, the percentage of FcAR positive U937 cells (mean \pm 1 SD) was $7.9 \pm 2.6 \%, 3.8 \pm 0.5 \%$, and $14.6 \pm 0.7 \%$ detected by IgA-IC at 2:1, 1:1, and 1:2 ratios, respectively. No positive cells were detected by anti-IgA or IgA alone. Thus IgA-IC at a 1:2 ratio was used in subsequent experiments. The range of FcAR+ cells in gamma-IFN treated U937 was 10-20\% detected by IgA-IC (1:2 ratio). We also discovered that $\mathrm{K} 562$, an erythro-myeloid leukemia cell line known to bear FcGR (26), constitutively expresses FcAR. The range of FcAR+ unstimulated K562 cells detected by IgA-IC at a 1:2 ratio was 30-60\% while no FcAR + K562 cells were detected by anti-IgA or IgA alone.

For specificity controls, uninduced U937, which is FcER and FcGR positive, and $\mathrm{K} 562$, which is FcAR and FcGR positive were used $(26,27)$. No FcAR were detected on uninduced U937 and no FcER were detected on K562. Furthermore, when RPMI 8866 or $\mathrm{K} 562$ cells were preincubated with purified human IgE or IgA $(10 \mu \mathrm{l}$ of 
a $1-\mathrm{mg} / \mathrm{ml}$ solution for $10 \mathrm{~min}$ ) before staining, FcER or FcAR detection was completely inhibited in an isotype-specific fashion.

Detection of FcGR+ cells. FcGR on NK cells was detected by enumerating Leu $11+$ NK cells $(19,20)$. Leu $11+$ cells were measured by laser flow cytometry (Ortho-Spectrum III) using anti-Leu 11a (Becton Dickinson Monoclonal Center, Inc., Mountain View, CA).

Separation of and supernatant production by FcR+ and FcR-NK cells. NK cells $\left(2 \times 10^{6} / \mathrm{ml}\right)$ were first cultured with IgE-IC or IgA-IC $(0.1 \mu \mathrm{g} / \mathrm{ml})$ for $16 \mathrm{~h}$. Then by means of immune adherence using anti-FcER antibody (MAb-135) or IgA-IC, different FcR+ and FcRpopulations were separated $(9,18)$. IC precultured NK cells $\left(2 \times 10^{7} /\right.$ $\mathrm{ml})$ were washed and incubated with MAb-135 or IgA-IC $(10 \mu \mathrm{g} / \mathrm{ml})$ for $60 \mathrm{~min}$ at $4^{\circ} \mathrm{C}$. After resuspension at $5 \times 10^{6} / \mathrm{ml}$ in PBS with $5 \%$ FCS, the cells were poured into $100 \mathrm{~mm}$ plastic petri dishes. These dishes had been preincubated for overnight at $4^{\circ} \mathrm{C}$ with $6 \mathrm{ml}$ of $\mathrm{F}(\mathrm{ab})^{\prime} 2$ goat anti-mouse IgG Fc (Jackson) at $20 \mu \mathrm{g} / \mathrm{ml}$, and covered with PBS with $5 \% \mathrm{BSA}$ and washed as above. After $90 \mathrm{~min}$ incubation at $4^{\circ} \mathrm{C}$, the nonadherent cells (FcER - or FcAR - cells) were removed by gentle swirling and aspiration. The adherent cells (FcER+ or FcAR+ cells) were then removed by vigorous washing. The percentage of cells recovered in the FcER+ or FcAR+ fractions were 4-7\% of total NK cells. After washing four times with warm medium, both FcR+ and FcRenriched NK cells $\left(1 \times 10^{6} / \mathrm{ml}\right)$ were cultured in CRPMI for a further 2 $d$ and the culture supernatants collected. These supernatants contained no detectable $(<300 \mathrm{pg} / \mathrm{ml})$ IgE or IgA.

Culture of Ig secreting cell lines. U266/AF-10 (AF-10) is a mycoplasma free stable IgE secreting subclone developed in our laboratory from the IgE plasmacytoma line U266 kindly provided by Dr. Kenneth Nilsson from the Laboratory of Tumor Biology, Department of Pathology, University Hospital, Uppsala, Sweden. GM-1500 and GM-1056 are IgG and IgA secreting lymphoblastoid cell lines, respectively (9). Mixtures of $5 \times 10^{3}$ of each cell line were cultured in 200 $\mu \mathrm{l} /$ well with $5 \times 10^{4}$ of medium or IC stimulated NK cells, or with supernatants ( $50 \%$ vol/vol) from FcER+, FcER-, FcAR+, or FcARNK cell populations. After culture for $3 \mathrm{~d}$, the amount of IgE, IgG, and IgA in the B cell culture medium was measured by isotype-specific ELISAs (15). Results are expressed as percent change of control Ig synthesis using the equation: \% change of control $=(X / Y-1) \times 100$, where $Y$ is the amount of net $\mathrm{Ig}$ (IgE, IgG, or IgA) produced by AF-10, GM-1500 or GM-1056 cultured with control medium and $X$ is the amount of Ig produced in the experimental cultures. The amount of Ig in cycloheximide treated $(50 \mu \mathrm{g} / \mathrm{ml})$ cultures was subtracted from the cell cultures to obtain net Ig production. The mean value of $Y$ was calculated from three or four wells, and the mean and standard deviation of percent change were calculated by dividing the value in a set of wells (three or four) by the value of $Y$. In some experiments, cells from individual lines $\left(5 \times 10^{3} /\right.$ well $)$ were cultured for $2 \mathrm{~d}$ with the NK supernatants $(50 \% \mathrm{vol} / \mathrm{vol})$ and then pulsed with $2 \mu \mathrm{Ci}$ of $\left[{ }^{3} \mathrm{H}\right]-$ thymidine. $16 \mathrm{~h}$ later, the cells were harvested and thymidine incorporation was determined. Simultaneously, Ig in the supernatants was measured. Statistical analysis was performed with the two-tailed Student's $t$ test.

The possibility of cytophilic IgE or IgA being carried over into cultures with IC-treated NK cells was excluded several ways. Frozen thawed (three times) NK cells failed to show enhancement of IgE or IgA synthesis from the B cell lines. No IgE or IgA $(<300 \mathrm{pg} / \mathrm{ml})$ was detected in cycloheximide-treated cultures containing the IC-stimulated NK cells. Also, when IgE-IC stimulated and washed NK cells were added to GM-1500 or GM-1056, no IgE was detected in the culture supernatants and no IgA was detected when IgA-IC stimulated and washed NK cells were added to AF-10 or GM-1500.

\section{Results}

FCER and FCAR are induced on NK cells by IC in an isotype specific fashion. No FcER+ and a few FcAR+ cells $(0.8 \pm 0.5 \%)$ were detected on freshly isolated NK $(\mathrm{NKH}-1+)$ cells from
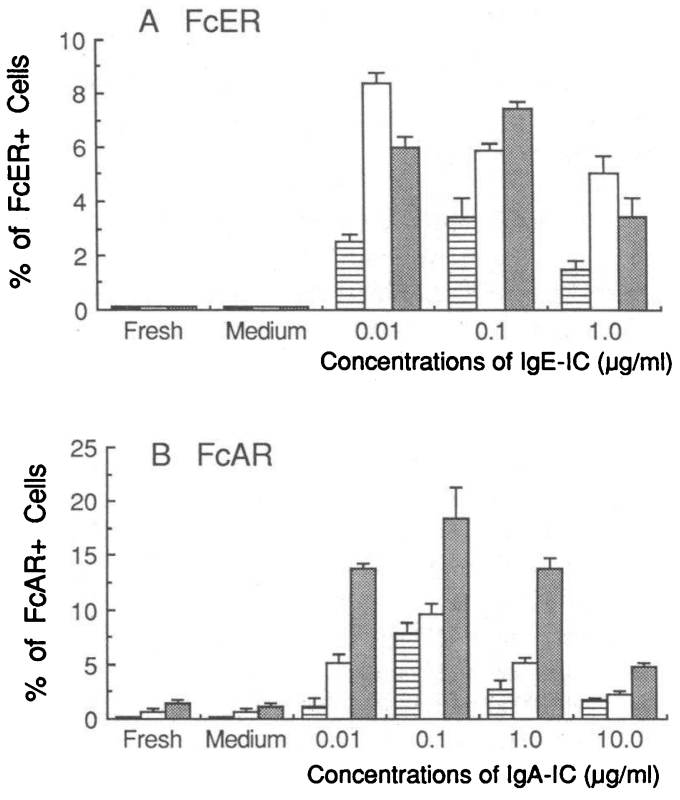

Figure 1. FcER and FcAR induction on NK cells by defined immune complexes. NK cells $\left(2 \times 10^{6} / \mathrm{ml}\right)$, cultured for $16 \mathrm{~h}$ with medium alone or differing concentrations of $\operatorname{IgE}-\operatorname{IC}(A)$ or $\operatorname{IgA}-\operatorname{IC}(B)$, were assayed for FcER $(A)$ or FcAR $(B)$ display. Results from three different experiments are shown as are results with fresh cells. The bar represents mean $\pm 1 \mathrm{SD}$ of three samples.

normal donors. When NK cells were incubated with IgE-IC or IgA-IC for $16 \mathrm{~h}$, FcER + (Fig. $1 A$ ) or FcAR + (Fig. $1 B$ ) NK cells were induced. In 10 donors, $4.8 \pm 2.3 \%$ (range $2.1-10.0 \%$ ) FcER + cells were induced by IgE-IC while $10.1 \pm 4.7 \%$ (range 3.9-20.1\%) FcAR + cells were induced by IgA-IC (Fig. 2) in an
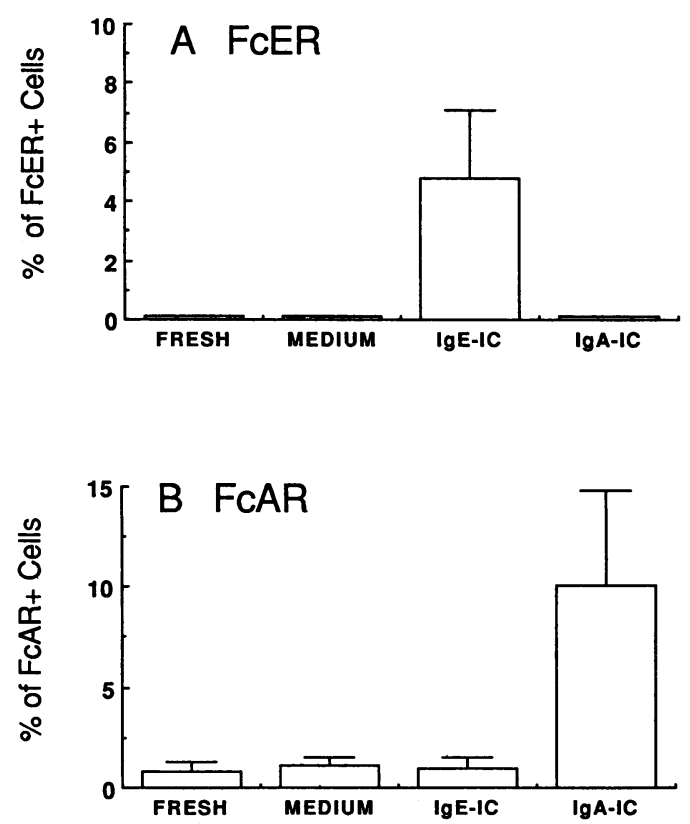

Figure 2. Immune complexes induce FcER or FcAR in an isotypespecific fashion. NK cells $\left(2 \times 10^{6} / \mathrm{ml}\right)$ were incubated with medium, $\operatorname{IgE}-\mathrm{IC}(0.1 \mu \mathrm{g} / \mathrm{ml})$ or IgA-IC $(0.1 \mu \mathrm{g} / \mathrm{ml})$ for $16 \mathrm{~h}$ and assayed for FcER $(A)$ or FcAR $(B)$ display. The bar represents mean \pm 1 SD of 10 experiments. 
isotype-specific fashion. FcER+ or FcAR+ cells were induced after $6 \mathrm{~h}$ of incubation with IC, reached a maximum after $24 \mathrm{~h}$ and declined thereafter (Fig. 3). FcGR (CD16) display was not altered by incubation with medium, IgE-IC or IgA-IC $(91 \pm 1 \%$, $92 \pm 2 \%$, and $91 \pm 1 \%$, respectively).

To confirm the specificity of the FcER immunohistochemical assay, we measured FcER + cells using a monoclonal antiFcER antibody (MAb-135) or IgE-IC constructed with a different IgE myeloma protein (epsilon kappa). The percentage (mean $\pm 1 \mathrm{SD}$ of three experiments) of IgE-IC-induced $(0.1$ $\mu \mathrm{g} / \mathrm{ml}$ PS-7.12) FcER + NK cells detected by IgE lambda-IC (PS-7.12), IgE kappa-IC (IgE kappa-7.12), and MAb-135 were $4.6 \pm 0.4,4.7 \pm 0.6$, and $5.1 \pm 0.8$, respectively. None of the reagents detected FcER + cells in fresh or medium incubated NK cells. IgE-IC $(0.01-1.0 \mu \mathrm{g} / \mathrm{ml})$ constructed between heat-inactivated IgE and anti-IgE (PS-7.12) failed to induce FcER detected by either IgE-IC or MAb-135 (0\% in five experiments). Similarly, $0.1 \mu \mathrm{g} / \mathrm{ml}$ of IgA alone, anti-IgA alone or IgA-IC consisting of $\operatorname{IgA}$ to anti-IgA at a ratio of $1: 1$ failed to induce FcAR.

Although IL-2 is a potent stimulator of NK cells (28), recombinant IL-2 (100 U/ml; Amgen, Thousand Oaks, CA) incubation ( $16 \mathrm{~h}$ ) did not induce FcER or FcAR on the NK cells. Since detection of FcER by MAb-135 was more sensitive than by IgE-IC, FcER was detected by MAb-135 in subsequent experiments. Moreover by using two-color immunofluorescence, $5 \%$ of FcER + and $12 \%$ of FcAR + cells were detected in $\mathrm{CD}^{+} 6^{+}$(FcGR) cells.

To assess coexpression of FcER and FcAR, we incubated NK cells with IgE-IC and IgA-IC alone or in combination. The two IC did not inhibit each other since both maneuvers induced similar percentage of FcER+ or FcAR+ cells. NK cells incubated with IgE-IC plus IgA-IC were then separated into FcR+ enriched (FcER+ or FcAR+) or depleted (FcER- or FcAR-) populations and the number of FcER+ or FcAR+ cells in each population determined. As shown in Table I, FcAR + cells were equally distributed in the FcER + or FcERpopulations, while similar percentage of FcER + cells was found in the FcAR+ or FcAR - populations, suggesting that both FcER and FcAR are induced on some NK cells simultaneously.

Induction of FCER or FCAR by IC requires protein and $R N A$ synthesis. Incubation of NK cells with IgE-IC $(0.1 \mu \mathrm{g} / \mathrm{ml})$ induced 5.0 $\pm 0.6 \%$ FcER + cells (detected by MAb-135) while
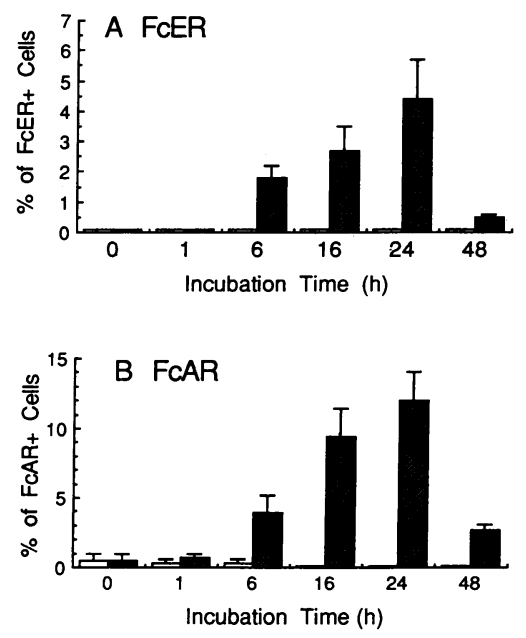

Figure 3. Kinetics of FcER $(A)$ or FcAR $(B)$ induction. NK cells $(2$ $\times 10^{6} / \mathrm{ml}$ ) were cultured for various time up to $48 \mathrm{~h}$ with IgE-IC $(0.1$ $\mu \mathrm{g} / \mathrm{ml}, \boldsymbol{\nabla})(A)$ or IgA-IC $(0.1 \mu \mathrm{g} / \mathrm{ml}, \mathrm{g})(B)$. The cells were then washed and assayed for FcER $(A)$ or FcAR $(B)$ compared to cells in medium alone ( $\square$ ). Results are the mean \pm 1 SD of six samples from two experiments.
Table I. Coexpression of FcER and FCAR by Coculture with IgE-IC plus IgA-IC

\begin{tabular}{ccc}
\hline & \multicolumn{2}{c}{ Percent FcR+ cells } \\
\cline { 2 - 3 } Cell population & FcER & FcAR \\
\hline FcER+ & $87.1 \pm 5.0$ & $10.3 \pm 1.4$ \\
FcER- & 0 & $10.1 \pm 1.8$ \\
FcAR+ & $4.8 \pm 0.7$ & $88.8 \pm 4.2$ \\
FcAR- & $5.0 \pm 0.6$ & 0 \\
\hline
\end{tabular}

Results are expressed as mean \pm 1 SD of triplicate cultures.

addition of cycloheximide $(50 \mu \mathrm{g} / \mathrm{ml})$ or actinomycin $\mathrm{D}(0.4$ $\mu \mathrm{g} / \mathrm{ml})$ completely abolished this FcER induction $(0 \%$ FcER+). In contrast, irradiation did not affect induction $(5.0 \pm 0.9 \%)$. Similarly, cycloheximide or actinomycin D completely abolished FcAR induction $(10.4 \% \pm 1.4 \%$ to $0.7 \pm 0.3 \%)$

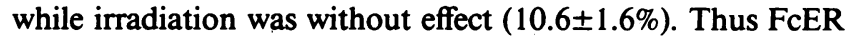
and FcAR induction require protein, RNA but not DNA synthesis as previously reported for FcER induction in the rat (29).

Immune complexes (IgE-IC or IgA-IC) induce FcER or FCAR on CD3 negative NKH-1 positive cells. Since a minor population of NKH-1 + cells are CD3+/CD16- (T cells). The CD3 - and CD3+ populations of NKH-1 + cells were separated and incubated with IgE-IC or IgA-IC. IC induced FcER or FcAR on CD3 - but not on CD3 + NKH-1 + cells (Table II). No FcER+ and a few FcAR+ cells $(0.6 \pm 0.4 \%)$ were detected in either freshly separated cell population. T cells depleted of NKH-1 + cells (NKH-1-/CD3+) were not be induced to express FcER or FcAR. IL-2 $(100 \mathrm{U} / \mathrm{ml})$ plus IgE-IC or IgA-IC failed to induce FcER or FcAR on CD3+ cells (data not shown).

FcER and/or FcAR induction is abnormal on NK cells from patients with altered serum Ig levels. Table III shows that as in normal donors no FcER + and a few FcAR + cells were detectable on fresh or medium incubated NK cells (data not shown) from the patients. In contrast to normal donors, IgE-IC did not

Table II. Induction of FCR on CD3 Positive or Negative NKH-1+Cells

\begin{tabular}{|c|c|c|}
\hline \multicolumn{2}{|c|}{ Cells + immune complexes } & \multirow{2}{*}{$\begin{array}{c}\text { Percent FcR } \\
\text { FcER } \\
\end{array}$} \\
\hline \multirow{2}{*}{\multicolumn{2}{|c|}{ A }} & \\
\hline & + IgE-IC & $5.0 \pm 0.7^{*}$ \\
\hline NKH-1 +/CD3- & + IgE-IC & $5.3 \pm 0.6^{*}$ \\
\hline $\mathrm{NKH}-1+/ \mathrm{CD} 3+$ & + IgE-IC & 0 \\
\hline NKH-1-/CD3+ & + IgE-IC & 0 \\
\hline & & FcAR \\
\hline \multicolumn{2}{|l|}{ B } & \\
\hline NKH-1+ & + IgA-IC & $10.2 \pm 0.7^{*}$ \\
\hline NKH-1+/CD3- & + IgA-IC & $10.8 \pm 0.7^{*}$ \\
\hline NKH-1+/CD3+ & + IgA-IC & $1.0 \pm 0.3$ \\
\hline NKH-1-/CD3+ & $+\operatorname{IgA}-\mathrm{IC}$ & $0.5 \pm 0.5$ \\
\hline
\end{tabular}

Results are expressed as mean \pm 1 SD of triplicate cultures. $* P<0.01$ compared with unstimulated cultures. 
Table III. Induction of FcER or FcAR on NK Cells from Patients

\begin{tabular}{|c|c|c|c|}
\hline \multirow[b]{2}{*}{ Patient No. } & \multirow{2}{*}{$\begin{array}{l}\text { Incubation of } \\
\text { NK cells with }\end{array}$} & \multicolumn{2}{|c|}{ Percent FcR } \\
\hline & & FcER & FcAR \\
\hline \multirow{3}{*}{$\begin{array}{l}\text { Hyper IgE } \\
\text { immunodeficiency } \\
(n=3)\end{array}$} & Fresh NK & 0 & $0.9 \pm 0.6$ \\
\hline & IgE-IC & 0 & $0.9 \pm 0.4$ \\
\hline & IgA-IC & 0 & $9.1 \pm 1.8^{*}$ \\
\hline \multirow[t]{3}{*}{ Atopic dermatitis $(n=3)$} & Fresh NK & 0 & $0.7 \pm 0.6$ \\
\hline & IgE-IC & 0 & $0.6 \pm 0.5$ \\
\hline & IgA-IC & 0 & $9.7 \pm 1.7^{*}$ \\
\hline \multirow[t]{3}{*}{ IgA myeloma $(n=2)$} & Fresh NK & 0 & $0.5 \pm 0.4$ \\
\hline & IgE-IC & $5.7 \pm 0.9^{*}$ & $0.9 \pm 0.3$ \\
\hline & IgA-IC & 0 & $0.8 \pm 0.3$ \\
\hline \multirow{3}{*}{$\begin{array}{l}\text { Selective IgA deficiency } \\
\quad(n=2)\end{array}$} & Fresh NK & 0 & $1.4 \pm 0.3$ \\
\hline & IgE-IC & $7.0 \pm 1.6^{*}$ & $1.2 \pm 0.3$ \\
\hline & IgA-IC & 0 & $1.3 \pm 0.6$ \\
\hline \multirow{3}{*}{$\begin{array}{l}\text { Dysgammaglobulinemia } \\
\text { type I }(n=1)\end{array}$} & Fresh NK & 0 & $1.4 \pm 0.2$ \\
\hline & IgE-IC & 0 & $1.0 \pm 0.2$ \\
\hline & IgA-IC & 0 & $1.2 \pm 0.2$ \\
\hline \multirow[t]{3}{*}{$\operatorname{CVI}(n=3)$} & Fresh NK & 0 & $0.6 \pm 0.6$ \\
\hline & IgE-IC & 0 & $0.8 \pm 0.4$ \\
\hline & IgA-IC & 0 & $0.5 \pm 0.5$ \\
\hline
\end{tabular}

Results are mean \pm 1 SD of triplicate cultures.

${ }^{*} P<0.01$ compared with unstimulated cells.

induce FcER on NK cells from patients with high serum IgE (hyper IgE immunodeficiency or atopic dermatitis) while IgAIC did induce FcAR. IgA-IC did not induce FcAR on NK cells from patients with high serum IgA (IgA myeloma) or conversely, absent serum IgA (selective IgA deficiency) while FcER was induced by IgE-IC. NK cells from patients with absent serum IgE or IgA (dysgammaglobulinemia type I or common variable immunodeficiency) were not induced to display FcER or FcAR. Incubation of these patients' cells with differing concentrations $(0.01-10 \mu \mathrm{g} / \mathrm{ml})$ of IC or varying period (1-48 h) failed to induce FcER and/or FcAR. Moreover, in patients with high serum IgE or IgA levels, failure of detection/induction of FcER or FcAR was not due to cytophilic IgE or IgA occupying the receptors, since fresh washed or incubated NK cells were stained with anti-IgE or anti-IgA antibody and no positive cells were found.

The failure of patients' NK cells to express FcER could be due to a defect in their NK cells ability to be induced for this receptor or a specific defect in response to IgE-IC. Normal and CVI patients' separated B and NK cells were incubated for $3 \mathrm{~d}$ with $100 \mathrm{U}$ of IL-4 (kindly provided by Dr. T. Yokata and Ms. A. V. Kimmende, DNAX Inc., Palo Alto, CA) as IL-4 induces FcER on B cells of normals and CVI patients (30). IL-4 failed to induce FcER on patient NK cells while it induced FcER expression (CD23) on up to 8\% and both NKH-1+ or Leu 11+ cells from normals. Both patients' and normals' B cells showed FcER induction by IL-4, being 60 and $40 \%$, respectively.

Effect of patients' IC stimulated NK cells on Ig synthesis by $B$ cell lines. We have previously shown that IgE-IC incubated NK cells from normal donors can enhance IgE synthesis in an isotype-specific fashion, without affecting NK cytolysis (15). Analogous results were obtained by incubating normal NK cells with IgA-IC, i.e., IgA-IC incubated NK cells from normal donors enhanced IgA synthesis from GM-1056 cells more than control medium incubated NK cells in an isotype-specific fashion (Table IV). Like IgE-IC, IgA-IC incubation did not alter NK cytotoxicity (data not shown).

While medium incubated NK cells from the same patients as shown in Table III showed similar effects to normal's NK cells in altering ongoing Ig synthesis (15) (IgE synthesis was inhibited $30-50 \%$ while $\operatorname{IgA}$ and IgG synthesis were enhanced 40-70\% and $20-50 \%$, respectively), patients' IgE-IC or IgA-IC treated NK cells did not show the enhancing effects on specific isotypes. This correlated with the defective induction of FcER or FcAR (Table IV). Thus NK cells from patients with high serum IgE levels further enhanced IgA synthesis after incubation with IgA-IC but their NK cells treated with IgE-IC did not show enhanced IgE induction capacity compared to medium incubated NK cells. Conversely, in patients with abnormal serum IgA levels, IgE synthesis was further enhanced by IgE-IC incubated NK cells while IgA synthesis was not further enhanced by incubation of NK cells with IgA-IC. In patients with absent serum IgE or IgA, neither IgE nor IgA synthesis was enhanced by incubation of NK cells with IgE-IC or IgA-IC. As in normals, incubation of NK cells with IgE-IC or IgA-IC failed to affect IgG synthesis compared to control medium incubated NK cells from these patients.

Supernatants from $\mathrm{FcR}+\mathrm{NK}$ cells alter Ig synthesis in an isotype preferential fashion. To test whether the induced FcR+ NK cells were responsible for enhancing isotype-specific Ig synthesis, we enriched FcR+ or FcR- cells as described in Methods. As shown in Fig. $4 A$, supernatants from FcER+ NK cells enhanced IgE synthesis significantly $(P<0.01)$, while supernatants from FcER - NK cells failed to do so. In contrast, supernatants from both populations $(<1 \% \mathrm{FcAR}+)$ failed to enhance IgA synthesis and enhanced IgG synthesis equally. Conversely, IgA synthesis was enhanced $(P<0.01)$ by super-

Table IV. Effect of IC Stimulated NK Cells on Ig Synthesis

\begin{tabular}{lcccr}
\hline & & \multicolumn{3}{c}{ Percent change of Ig synthesis } \\
\cline { 5 - 6 } \multicolumn{1}{c}{ Patient No. } & $\begin{array}{c}\text { Incubation of } \\
\text { NK cells with }\end{array}$ & IgE & IgA & IgG \\
\hline Hyper IgE & & & & \\
immunodeficiency & IgE-IC & $-2 \pm 3$ & $0 \pm 6$ & $1 \pm 6$ \\
$(n=3)$ & IgA-IC & $1 \pm 1$ & $42 \pm 6^{*}$ & $-1 \pm 1$ \\
Atopic dermatitis $(n=3)$ & IgE-IC & $-1 \pm 3$ & $3 \pm 3$ & $-3 \pm 4$ \\
& IgA-IC & $-1 \pm 1$ & $47 \pm 6^{*}$ & $-4 \pm 6$ \\
IgA myeloma $(n=2)$ & IgE-IC & $22 \pm 2^{*}$ & $-4 \pm 0$ & $2 \pm 2$ \\
& IgA-IC & $2 \pm 2$ & $0 \pm 2$ & $2 \pm 1$ \\
Selective IgA deficiency & IgE-IC & $26 \pm 3^{*}$ & $-3 \pm 1$ & $1 \pm 1$ \\
$(n=2)$ & IgA-IC & $-2 \pm 2$ & $0 \pm 3$ & $3 \pm 1$ \\
Dysgammaglobulinemia & IgE-IC & $-6 \pm 1$ & $-1 \pm 1$ & $-4 \pm 1$ \\
type I $(n=1)$ & IgA-IC & $-4 \pm 2$ & $-2 \pm 1$ & $0 \pm 1$ \\
CVI $(n=3)$ & IgE-IC & $0 \pm 2$ & $0 \pm 5$ & $2 \pm 2$ \\
& IgA-IC & $-2 \pm 2$ & $0 \pm 6$ & $-2 \pm 2$ \\
Normal donors $(n=3)$ & IgE-IC & $22 \pm 4^{*}$ & $3 \pm 6$ & $3 \pm 6$ \\
& IgA-IC & $2 \pm 2$ & $54 \pm 9^{*}$ & $4 \pm 2$ \\
& & & & \\
\hline
\end{tabular}

No Ig was detected in cultures of NK cells alone. Values are mean \pm 1 SD of triplicate cultures and expressed as: $\%$ change $=($ Ig with IC stimulated NK - Ig with medium treated NK cells)/(Ig in control culture with no NK cells). The range of control net IgE, IgA, and IgG synthesis were $50-55,140-150$, and $130-140 \mathrm{ng} / \mathrm{ml}$, respectively. ${ }^{*} P<0.01$. 

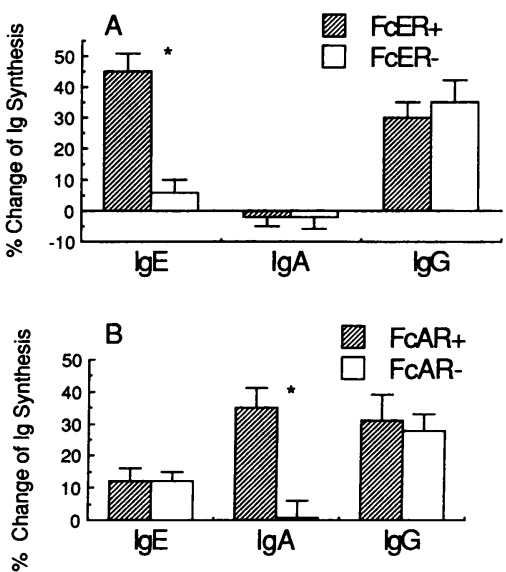

Results are expressed as percent change of control Ig (mean \pm 1 SD) of three experiments. Control net absolute IgE, IgA, and IgG synthesis were $58 \pm 4 \mathrm{ng} / \mathrm{ml}, 123 \pm 13 \mathrm{ng} / \mathrm{ml}$, and $125 \pm 10 \mathrm{ng} / \mathrm{ml}$, respectively. None of the NK cell supernatants contained detectable Ig. ${ }^{*} P$ $<0.01$. The FcER populations contained less than 1\% FcAR+ cells while the FcAR populations contained no detectable FcER+ cells.

natants from FcAR+ NK cells but not FcAR - NK cells. Again supernatants from both populations (no detectable FcER+) failed to enhance IgE synthesis significantly, while they enhanced IgG synthesis equally (Fig. 4 B). When 50, 25, and $12.5 \%$ supernatants were used to demonstrate a dose response, the percent enhancement of IgE synthesis by supernatants from FcER ${ }^{+} \mathrm{NK}$ cells were $45 \pm 6,29 \pm 9$, and $19 \pm 3$, respectively, while the \% enhancement of IgA synthesis by supernatants from FcAR ${ }^{+} \mathrm{NK}$ cells were 35 $36,21 \pm 2$, and 12 \pm 2 , respectively. Moreover, this enhancement was due to differentiation but not proliferation of the cell as FcER + NK cell supernatants enhanced IgE synthesis from AF-10 (44 $\pm 6 \%, P$ $<0.01)$ without increasing thymidine incorporation $(3 \pm 3 \%$ enhancement). Similarly supernatants from FcAR + NK cells enhanced IgA synthesis from GM-1056 (36 $14 \%, P<0.01)$ without affecting thymidine incorporation $(2 \pm 4 \%)$. Superna-

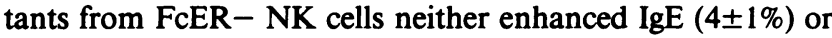
thymidine incorporation $(3 \pm 3 \%)$ by AF-10. Supernatants from FcAR - NK cells also failed to enhance IgA synthesis $(3 \pm 1 \%$ enhancement) or thymidine incorporation $(0 \pm 8 \%$ enhancement) by GM-1056. Control net Ig synthesis and thymidine incorporation were $52 \pm 3 \mathrm{ng} / \mathrm{ml}$ of $\mathrm{IgE}$ and $93,333 \pm 6,697$ cpm by AF-10, and $138 \pm 4 \mathrm{ng} / \mathrm{ml}$ of $\mathrm{IgA}$ and $64,454 \pm 4,540$ cpm by GM-1056, respectively.

\section{Discussion}

We have shown that NK (NKH-1+) cells from normal donors can be induced by IC containing specific human Ig class proteins (IgE or IgA) to express FcER or FcAR. Induction of NK cell Fc receptors was isotype-specific as IgE-IC did not affect FcAR or FcGR, and IgA-IC did not alter FcER or FcGR (Fig. 2). Moreover, some NK cells appeared to be induced to express FcER and FcAR simultaneously (Table I) in accordance with multiple $\mathrm{FcR}$ induction in an isotype-specific fashion on a $\mathrm{T}$ cell hybridoma (31). Although the average number of $\mathrm{FcER}^{+}$or $\mathrm{FcAR}^{+}$cells are 5 or $10 \%, \mathrm{NKH}^{-1}{ }^{+}$cells are heterogeneous as reported (19). Thus only a minor proportion of such cells may represent the response subset of $\mathrm{NKH}-1^{+}$cells. Moreover, even the cloned $\mathrm{T}$ cell hybridoma lines express $<10 \%$ of $\mathrm{FcER}^{+}$or $\mathrm{FcAR}^{+}$cells (31).

Induction of receptors on cells by ligands when the receptor was not initially detectable, such as we have described here for the FcER and FcAR is well documented. The IL-2 receptor (IL-2R) is induced by IL-2 (32), and FcR are induced by Igs of various isotypes $(8,31,33)$. Yodoi and Ishizaka (33) have shown that IgE induced FcER on cells depleted of FcER+ cells, Daeron et al. (31) have reported that FcER was induced by IgE on an FcER negative $T$ cell hybridoma and recently, Kisaki et al. (34) reported that an FcER negative human T cell hybridoma, upon incubation with monoclonal anti-FcER antibody, formed IgE binding factors suggesting the cells bear low numbers of FcER. It is likely that human NK cells express low affinity and/or few FcER or FcAR that are not detectable by our methods and IC stimulate such cells to greater and detectable FcR expression. Alternatively, though less likely, IC could stimulate NK cells through non-Fc receptors to express FcER or FcAR.

The detection of the FcER or FcAR on the induced NK cells was not due to either cytophilic IgE or IgA nor nonspecific binding of IC. No FcER + cells were induced or stained when using IgE-IC made with heat inactivated IgE (22). Similarly, anti-IgA alone or IgA-IC consisting of IgA to anti-IgA at a ratio of $1: 1$ failed to induce FcAR+ cells. Furthermore, staining of IC stimulated cells with biotinylated horse antimouse IgG directly followed by peroxidase reaction did not show any positive cells. Induction was IC concentration and time dependent (Figs. 1 and 3 ) and required protein and RNA synthesis. These results indicate that induction of receptors was due to active mechanisms. The detection of FcR was not an artifact of specific paraprotein as FcER was detected with IgE-IC constructed with two different human IgE paraproteins and monoclonal anti-FcER antibody (MAb-135) and FcAR detection was accomplished with IgA-IC constructed with polyclonal human IgA. The transient nature of FcER and FcAR induction was not surprising. Yodoi and Ishizaka have suggested half life of FcER on rat lymphocytes is less than several hours (33). Marcelletti and Katz have reported FcER induction on mouse lymphocytes was maximum at $8 \mathrm{~h}$ (35). Daeron et al. have reported that constitutive FcR are long-lived FcR while inducible FcR are short-lived (half-life 6-8 h) (31).

The detection of FcER on fresh $T$ cells is controversial. While FcER + cells were detected in E receptor (CD 11)+ cell population $(4,5)$, Suemura et al. (36) have reported that FcER was not detected or induced on $\mathrm{T}$ cells either from normal donors or atopic patients. Here we show that among the $\mathrm{E}$ receptor+ cells, FcER was induced on the non-T $\left(\mathrm{CD}^{-}\right)$ $\mathrm{NKH}-1+$ cells but not on $\mathrm{T}\left(\mathrm{CD}^{+}\right) \mathrm{NHK}-1$ positive or negative cells (Table II).

NK cells from patients with markedly elevated or decreased serum Ig levels showed an isotype restricted defect in FcER or FcAR expression. Failure of isotype specific FcR induction on NK cells in the face of absent serum Ig levels is in accord with previous reports. In SJA9 mice, which can not produce IgE antibody, FcER can not be induced by IgE while FcGR and FcAR expression was normal (37). In patients with CVI, FcER expression was decreased (30). In patients with selective IgA deficiency FcAR was not induced by IgA, while FcGR expression was normal (8). 
It appears that in vivo exposure to IgE and IgA provides a tropic effect for NK FcER and FcAR and in their absence, there is decreased responsiveness to induction. Failure of FcER or FcAR induction in patients with high serum IgE or IgA also has precedent. FcER was not detected on T cells ( $E$ receptor ${ }^{+}$cells) in atopic patients with very high serum IgE or in patients with hyper IgE immunodeficiency while they were detected in asymptomatic atopic patients with mildly elevated serum $\operatorname{IgE}(5,13,36)$. Polymeric $\operatorname{IgA}$ or IgA-IC can induce FcAR while monomeric IgA not only fails to induce FcAR but competes for binding of polymeric IgA or IgA-IC to the receptor (38). As in other biologic systems, chronic exposure to high ligand levels may cause decreased receptor expression $(39,40)$ though this is certainly not universally true, i.e., there is increased expression of FcER on B cells in patients with atopic dermatitis. It is likely that chronic in vivo elevation of monomeric IgE or IgA caused down regulation of FcER or FcAR on NK cells (but not B cells) and made them resistant to exogenous induction.

We have previously shown that IgE-IC treated NK cells from normals can enhance IgE synthesis in an isotype-specific fashion (15). Similarly we demonstrate here that NK cells preincubated with IgA-IC were specifically enhanced in their ability to induce IgA synthesis. In contrast, IC stimulated NK cells from patients showed defective enhancement of Ig synthesis correlating with defective induction of FcR (Tables III and IV), suggesting that the induced FcER+ or FcAR+ NK cells were responsible for the isotype specific enhancement of Ig synthesis. This was directly demonstrated as supernatants from FcER + or FcAR + NK cells enhanced Ig synthesis in an isotype-specific fashion (Fig. 4).

It has been reported that supernatants from FcER + T cell or $B$ cell lines contain IgE binding factors that can regulate IgE synthesis in an isotype-specific fashion $(6,41)$. The B cell IgE binding factor(s) is, in fact, a fragment(s) of the B cell FcER that can function as a growth factor (42). Our results suggest FcER on NK cells (which we also detected by anti-CD23 antibody) may also participate in regulating IgE responses (Fig. 4). The FcER on B cells (now known to be the CD23 antigen) (43) is induced by IL-4 (44) and is a receptor for a low molecular B cell growth factor (45) though whether it functions as a growth factor receptor on NK cells is unknown. Thus it is not surprising that supernatants from FcER + B cell lines contain B cell growth factor(s) (46). These IgE binding factors that presumably represent fragments of the FcER, from FcER + B or T cell lines, also affect IgE production from in vitro or in vivo IgE secreting cells $(41,47)$. Whether the IgE enhancement was due to proliferation or differentiation of IgE secreting $B$ cells is unknown. We found that FcER+ or FcAR+ NK cell supernatants provided a differentiation effect as there was enhanced IgE or IgA synthesis without an increase in proliferation/ growth (Fig. 4). IL-4 has been reported to induce FcER on B cells and enhance IgE and IgGl synthesis while relatively inhibiting other isotypes $(44,48)$. While it is possible that IgE-IC stimulated NK cells to produce IL-4, which in turn enhanced IgE synthesis from U266/AF-10, this is unlikely since human IL-4 (kindly provided by Dr. T. Yokota and Ms. A. V. Kimmenade, DNAX Inc, Palo Alto, CA) failed to enhance IgE synthesis from AF-10 (unpublished observation). Moreover, IL-4 induced FcER on B cells from our patients with CVI as has been previously reported (30), though IL-4 failed to induce FcER on NK cells from these patients.
NK cells, when activated in vivo, have been shown to produce lymphokines which may contribute to antibody formation in the absence of helper T cells (49). It is likely that NK cells induced in vivo to express FcR play a role in the regulation of the Ig isotype or subclass response. Our data support this concept that a subset of NK cells can be induced to display $\mathrm{FcR}$ for various $\mathrm{Ig}$ isotypes and such $\mathrm{FcR}+$ cells produce Ig isotype/subclass regulatory molecules.

\section{Acknowledgments}

We would like to thank Ms. Aimee Nguyen, Ms. Alexis Brown, and Dr. Francis Tsui for their excellent technical assistance, and Dr. Janis Giorgi, Ms. Ingrid Schmid, Ms. Marguerite Reilly, and Ms. Kathy Petersilie for help in measuring Leu $11+$ cells. We also would like to thank Drs. Susan Kanowith-Klein, Jonathan Kagan, and Elliott Sherr for their assistance and helpful discussions.

Supported by U. S. Public Health Service grants AI-15251, AI-15332, CA-12800, and CA-23175.

\section{References}

1. Neauport-Sautes, C., C. Rabourdin-Combe, and W. H. Fridman. 1979. T cell hybrids bear FcG receptors and secrete suppressor immunoglobulin binding factor. Nature (Lond.) 277:656-659.

2. Yodoi, J., and K. Ishizaka. 1980. Lymphocyte bearing Fc receptors for IgE. IV. Formation of IgE-binding factor by rat T lymphocytes. J. Immunol. 124:1322-1329.

3. Kiyono, H., L. M. Mosteller-Barnum, A. M. Pitts, S. I. Williamson, S. M. Michalek, and J. R. McGhee. 1985. Isotype-specific immunoregulation. IgA-binding factors produced by $\mathrm{FcA}$ receptor-positive T cell hybridoma regulate IgA responses. J. Exp. Med. 161:731-747.

4. Yodoi, J., and K. Ishizaka. 1980. Induction of FcE-receptor bearing cells in vitro in human peripheral lymphocytes. J. Immunol. 124:934-938.

5. Thompson, L. F., M. H. Mellow, R. S. Zeiger, and H. L. Spiegelberg. 1983. Characterization with monoclonal antibodies of $T$ lymphocytes bearing Fc receptor for IgE ( $T$ epsilon cells) and IgG ( $T$ gamma cells) in atopic patients. J. Immunol. 131:2772-2776.

6. Young, M. C., D. Y. M. Leung, and R. S. Geha. 1984. Production of IgE-potentiating factor in man by $\mathrm{T}$ cell lines bearing Fc receptor for IgE. Eur. J. Immunol. 14:871-878.

7. Lum, L. G., A. V. Muchmore, D. Keren, J. Decker, I. Koski, W. Strober, and R. M. Blease. 1979. A receptor for IgA on human T lymphocytes. J. Immunol. 122:65-69.

8. Adachi, M., J. Yodoi, T. Masuda, K. Takatsuki, and H. Uchino. 1983. Altered expression of lymphocytes FcA receptors in selective IgA deficiency and IgA nephropathy. J. Immunol. 131:1246-1251.

9. Hassner, A., and A. Saxon. 1984. Isotype-specific human suppressor $\mathrm{T}$ cells for IgE synthesis activated by IgE-anti-IgE immune complexes. J. Immunol. 132:2844-2849.

10. Timonen, T., A. Parki, E. Sakela, and P. Harry. 1979. Fractionation, morphological and functional characterization of effector cells responsible for human natural killer activity against cell-line targets. Cell. Immunol. 48:133-148.

11. West, W. H., G. B. Cannon, H. D. Kay, G. D. Bonnard, and R. B. Herberman. 1977. Natural cytotoxic reactivity of human lymphocyte against a myeloid cell line: characterization of the effector cell. J. Immunol. 118:355-361.

12. Galli, S. J., A. M. Dvorak, T. Ishizaka, G. Nabel, H. D. Simonian, H. Cantor, and H. F. Dvorak. 1982. A cloned cell with NK function resembles basophils by ultrastructure and express IgE receptors. Nature (Lond.). 298:288-290.

13. Thompson, L. F., H. L. Spiegelberg, and R. H. Buckley. 1985. IgE Fc receptor positive $\mathrm{T}$ and $\mathrm{B}$ lymphocytes in patients with the hyper IgE syndrome. Clin. Exp. Immunol. 59:77-84. 
14. Vyakarnam, A., M. K. Brenner, J. E. Reittie, C. H. Houlker, and P. J. Lachmann. 1985. Human clones with natural killer function can activate B cells and secrete B cell differentiation factors. Eur. J. Immunol. 15:606-610.

15. Kimata, H., F. Shanahan, M. Brogan, S. Targan, and A. Saxon. 1987. Modulation of ongoing human immunoglobulin synthesis by natural killer cells. Cell. Immunol. 107:74-88.

16. Boyum, A. 1968. Isolation of mononuclear cells and granulocytes from human blood. Scan. J. Clin. Lab. Invest. 97(Suppl.):77-89.

17. Saxon, A., J. L. Feldhaus, and R. A. Robins. 1976. Single step separation of human T and B cells using AET-treated SRBC rosette. $J$. Immunol. Methods. 12:285-288.

18. Wysocki, L. J., and U. L. Sato. 1978. "Panning" for lymphocytes. A method for cell selection. Proc. Natl. Acad. Sci. USA. 75:2844-2848.

19. Lanier, L. L., A. M. Le, C. I. Civin, M. R. Loken, and J. H. Philips. 1986. The relationship of CD16 (Leu-11) and Leu-19 (NKH-1) antigen expression on human peripheral blood NK cells and cytotoxic T lymphocytes. J. Immunol. 136:4480-4486.

20. Perussia, B., O. Acuto, C. Terhorst, J. Faust, R. Lazarus, V. Fanning, and G. Trinchieri. 1983. Human natural killer cells analyzed by B73.1, a monoclonal antibody blocking Fc receptor functions. II. Studies of B73.1 antibody-antigen interaction on the lymphocyte membrane. J. Immunol. 130:2141-2148.

21. Hercend, T., J. D. Griffin, A. Bensussan, R. E. Schmidt, M. A. Elson, A. Brennan, C. Murray, J. F. Dalet, S. F. Schlossman, and J. Ritz. 1985. Generation of monoclonal antibodies to a human natural killer clone: Characterization of the NK-associated antigen, NKH-1 $(200 \mathrm{KD})$ and $\mathrm{NKH}-2(60 \mathrm{KD})$ expressed on subsets of large granular lymphocytes. J. Clin. Invest. 75:932-943.

22. Kanowith-Klein, S., and A. Saxon. 1985. Fc epsilon receptor on human cell lines and peripheral blood lymphocytes detected by binding of IgE immune complexes. J. Clin. Immunol. 5:38-45.

23. Ishizaka, K., T. Ishizaka, and A. Menzel. 1967. Physiochemical properties of reaginic activity. VI. Effect of heat on gamma $\mathrm{E}$, gamma $G$ and gamma $A$ antibodies in the sera of ragweed sensitive patients. $J$. Immunol. 99:610-618.

24. Gonzalez-Molina, A., and H. L. Spiegelberg. 1976. Binding of IgE myeloma proteins to human cultured lymphoblastoid cells. $J$. Immunol. 117:1838-1845.

25. Rector, E., T. Nakajima, C. Rocha, D. Duncan, D. Lestourgeon, R. S. Mitchell, J. Fisher, A. H. Sehon, and G. Delespesse. 1985. Detection and characterization of monoclonal antibodies specific for IgE receptors on human lymphocytes by flow cytometry. Immunology. 55:481-488.

26. Looney, R. J., G. N. Abraham, and C. L. Anderson. 1986. Human monocytes and U937 cells bear two distinct Fc receptors for IgG. J. Immunol. 136:1641-1647.

27. Anderson, C. L., and H. L. Spiegelberg. 1981. Macrophage receptors for IgE: binding of IgE to specific IgE Fc receptors on a human macrophage cell line, U937. J. Immunol. 126:2470-2473.

28. Lanier, L. L., C. J. Benike, J. H. Phillips, and E. G. Engelman. 1985. Recombinant interleukin 2 enhanced natural killer cell-mediated cytotoxicity in human lymphocyte subpopulations expressing the Leu 7 and Leu 11 antigens. J. Immunol. 134:794-801.

29. Yodoi, J., T. Ishizaka, and K. Ishizaka. 1979. Lymphocyte bearing Fc receptors for IgE. II. Induction of FcE-receptor bearing rat lymphocytes by IgE. J. Immunol. 123:455-462.

30. Kikutani, H., M. Suemura, H. Owaki, H. Nakamura, R. Sato, K. Yamasaki, E. L. Barsumian, R. R. Hardy, and T. Kishimoto. 1986. FcE receptor, a specific differentiation marker transiently expressed on mature B cells before isotype switching. J. Exp. Med. 164:1455-1469.

31. Daeron, M., C. Neauport-Sautes, J. Yodoi, J. Moncuit, and W. H. Fridman. 1985. Receptors for immunoglobulin isotypes (FcR) on murine $\mathrm{T}$ cells. II. Multiple $\mathrm{FcR}$ induction on hybridoma $\mathrm{T}$ cell clones. Eur. J. Immunol. 15:668-674.
32. Welte, K., M. Andreeff, E. Platzer, K. Holloway, B. Y. Rubin, M. A. S. Moore, and R. Mertelesmann. 1984. Interleukin 2 regulates the expression of Tac antigen on purified blood T lymphocytes. J. Exp. Med. 160:1390-1403.

33. Yodoi, J., and K. Ishizaka. 1979. Lymphocyte bearing receptors for IgE. III. Transition of FcGR( + cells to FcER( $(+)$ cells by IgE. $J$. Immunol. 123:2004-2010.

34. Kisaki, T., T. F. Huff, D. H. Conrad, J. Yodoi, and K. Ishizaka. 1987. Monoclonal antibody specific for T cell-derived human $\operatorname{IgE}$ binding factors. J. Immunol. 138:3345-3551.

35. Marcelletti, J. F., and D. H. Katz. 1984. FcRE+ lymphocytes and regulation of the IgE antibody system. II. FcRE+ B lymphocytes initiate a cascade of cellularand molecular interactions that control FcRE expression and IgE production. J. Immunol. 133:2829-2836.

36. Suemura, M., H. Kikutani, E. L. Barusumian, Y. Hattori, S Kishimoto, R. Sato, A. Maeda, H. Nakamura, H. Owaki, R. R. Hardy, and T. Kishimoto. 1986. Monoclonal anti-FcE receptor antibody with different specificities and studies on the expression of FcE receptors on human B and T cells. J. Immunol. 137:1214-1220.

37. Adachi, M., K. Okumura, N. Watanabe, N. Noro, T. Masuda, and J. Yodoi. 1985. Lack of Fc receptor for IgE in SJA9 mice. Immunogenetics. 22:77-83.

38. Yodoi, J., M. Adachi, and T. Masuda. 1982. Induction of FcAR on murine lymphocytes by IgA in vitro. J. Immunol. 128:888-894.

39. Archer, J. A., P. Gorden, J. R. Gavin III, M. A. Lesniak, and J. Roth. 1973. Insulin receptors in human circulating lymphocytes: application to study of insulin resistance in man. J. Clin. Endocrinol. Metab. 36:627-633.

40. Micky, J., R. Tate, and R. J. Lefkowitz. 1975. Subsensitivity of adenyl cyclase and decreased beta-adrenergic receptor binding after chronic exposure to (-)-isoproterenol in vitro. J. Biol. Chem. 250:5727-5729.

41. Sarfati, M., E. Rector, M. Rubio-Trujillo, K. Wong, A. H. Sehon, and G. Delespesse. 1984. In vitro synthesis of IgE by human lymphocytes. III. IgE-potentiating activity of culture supernatants from Epstein-Barr virus (EBV) transformed B cells. Immunology. 53:207-214.

42. Swendeman, S., and D. A. Thorley-Lawson. 1987. The activation antigen BLAST-2, when shed, is an autocrine BCGF for normal and transformed B cells. Eur. Mol. Biol. Organ. J. 6:1637-1642.

43. Yukawa, K., H. Kikutani, H. Owaki, K. Yamasaki, A. Yokota, H. Nakamura, E. L. Barsumian, R. R. Hardy, M. Suemura, and T. Kishimoto. 1987. A B cell-specific differentiation antigen, CD23, is a receptor for IgE (FcER) on lymphocytes. J. Immunol. 138:2576-2580.

44. Defrance, T., J. P. Aubry, F. Rousset, B. Vanbervliet, J. Y. Bonnefoy, N. Arai, Y. Takebe, T. Yokota, F. Lee, K. Arai, J. D. Vries, and J. Banchereau. 1987. Human recombinant interleukin 4 induces FcE receptors (CD23) on normal human B lymphocytes. J. Exp. Med. 165:1459-1467.

45. Gordon, J., A. J. Webb, L. Walker, G. R. Guy, and M. Rowe. 1986. Evidence for an association between CD23 and the receptor for a low molecular weight B cell growth factor. Eur. J. Immunol. 16:16271630.

46. Gordon, J., S. C. Ley, M. D. Melamed, L. S. English, and N. C. Hughes-Jones. 1984. Immortalized B lymphocytes produce B-cell growth factor. Nature (Lond.). 310:145-147.

47. Young, M., R. S. Geha, K. N. Maksad, and D. Y. M. Leung. 1986. Characterization of human $T$ cell-derived IgE-potentiating factor. Eur. J. Immunol. 16:985-991.

48. Coffman, R. L., J. Ohara, M. W. Bond, J. Carty, A. Zlotnik, and W. E. Paul. 1986. B cell simulatory factor-1 enhances the IgE response of lipopolysaccharide-activated B cells. J. Immunol. 136:4538-4541.

49. Brenner, M. K., A. Vyarkanam, J. E. Reittie, J.-Ph. Grob, and H. G. Prentice. 1986. Induction of B cell differentiation by large granular lymphocytes (LGL) that have been activated in vivo. 6th International Congress of Immunology in Toronto. 3.51.21. (Abstr.) 